\title{
Toxic side effects of local anaesthetics on the human
}

\section{cornea}

\author{
M Boljka, G Kolar, J Videnšek
}

\section{Department of \\ Ophthalmology, \\ University Ljubliana, \\ Slovenija \\ M Boljka \\ G Kolar \\ J Videnšek \\ Correspondence to: \\ Dr M Boljka, Okulistična \\ klinikia, Ljubljana 61000 \\ Zaloška 2, Slovenija. \\ Accepted for publication \\ 13 December 1993}

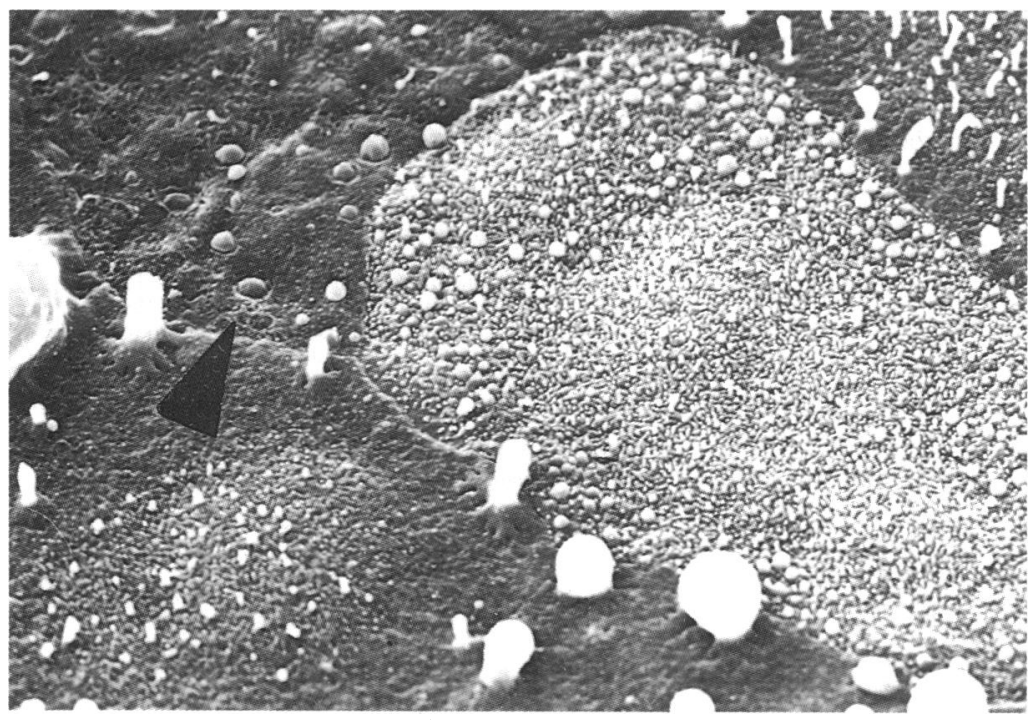

Figure 1 The corneal surface following application of $0.5 \%$ amethocaine. Numerous amethocaine deposits of various sizes $(0 \cdot 2-3 \cdot 0 \mu \mathrm{m})$ are seen. A deposit being engulfed (arrow) $(S E M \times 2200)$.

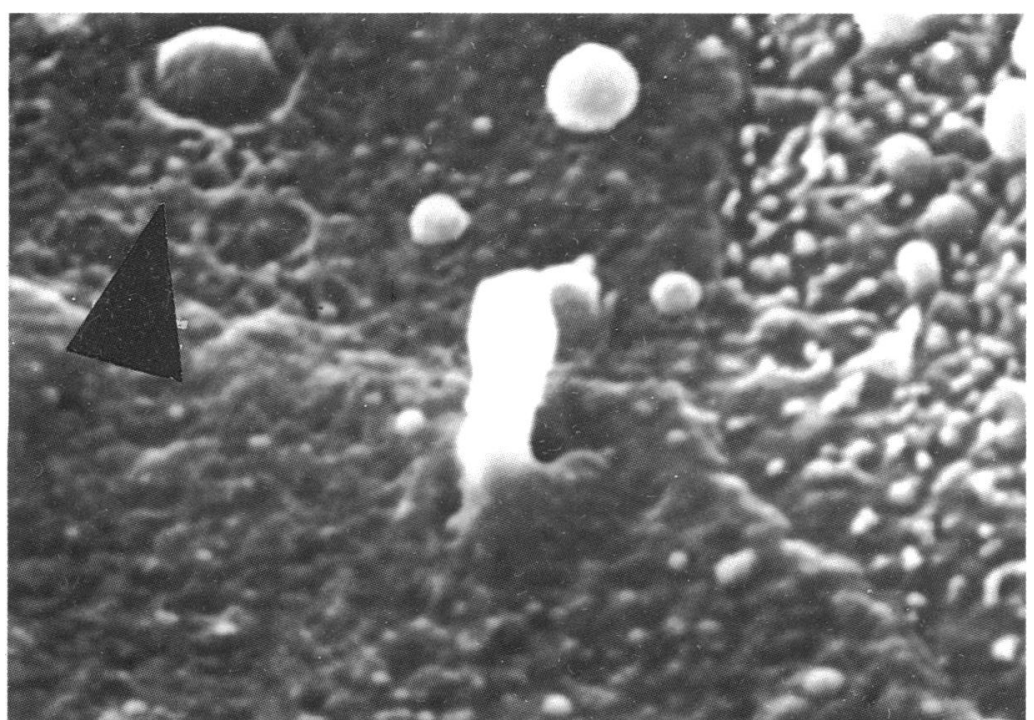

Figure 2 Higher magnification of Figure 1. Deposit (arrow) engulfed into the damaged cell membrane of a 'dark' cell devoid or microvilli $(S E M \times 10000)$.

\begin{abstract}
The cytotoxic effects of $0.5 \%$ amethocaine (tetracaine) on the human cornea were investigated by scanning electron microscopy. The ultrastructural examination of epithelial cells showed damage of the cell membrane, rareloss of microvilli, deposits of erated desquamation of superficial epithelial cells.
\end{abstract}

(BrF Ophthalmol 1994; 78: 386-389)
Local anaesthetic drugs have the ability reversibly to block conduction of nerve impulses at the axonal membrane level. They diffuse through epithelial cells to reach the corneal nerves via the nodes of Ranvier. Because of their direct interaction with the specific binding sites within the $\mathrm{Na}^{+}$ channels in the axonal membrane, local anaesthetics interfere with the $\mathrm{Na}^{+}$influx through the membrane and reduce electrical excitability. ${ }^{1}$

\section{History}

The first local anaesthetic to be discovered was cocaine, an alkaloid contained in the leaves of Erythroxylon coca, first isolated by Niemann in $1860 .^{2}$ The clinical use of cocaine in ophthalmology was initiated by Koller ${ }^{3}$ and Knapp ${ }^{4}$ in 1884 . Soon after its surface anaesthetic property had been recognised, cocaine applied to the cornea was found to cause epithelial erosion. ${ }^{5}$ For that reason a chemical search for synthetic cocaine substitutes started. One of synthetic cocaine substitutes is $0.5 \%$ amethocaine, which is five to eight times stronger than cocaine,${ }^{6}$ its local anaesthesia is produced within 25 seconds and lasts for up to 15 minutes.

All local anaesthetics have severe toxic side effects after long term, uncontrolled overuse. Their toxicity was reported in patients with anaesthetic induced keratopathy. ${ }^{7-12}$ Common findings were extensive erosions and persistent epithelial defects. Perforating keratoplasty was even required to treat corneal perforation or severe corneal opacities, ${ }^{1314}$ and enucleation had to be performed to relieve intractable pain. ${ }^{15}$

Only animal (rabbit, ${ }^{16}$ rat $^{17}$ ) eyes are suitable for the investigations of pharmacodynamic properties of local anaesthetics, as they allow successive assessments of biochemical and morphological alterations of living cells. No report has been found on scanning electron microscopic investigation of the human cornea exposed to local anaesthetics, so in our study we used a human cornea.

\section{Materials and methods}

The side effects of $0.5 \%$ amethocaine were studied on two normal human corneas obtained by enucleation of eyes because of malignant choroidal melanoma. During the operation, the corneas were moistened constantly with a solution of $0.9 \% \mathrm{NaCl}$. Immediately after enucleation, the corneas were excised and halved. The first half was instilled with one drop of $0.5 \%$ amethocaine three times at 2 minute intervals, while the second half of the same cornea served as a control and was instilled with $0.9 \% \mathrm{NaCl}$ only. After 6 minutes, both halves of the same cornea were put into $2 \%$ glutaraldehyde for 2 hours and 


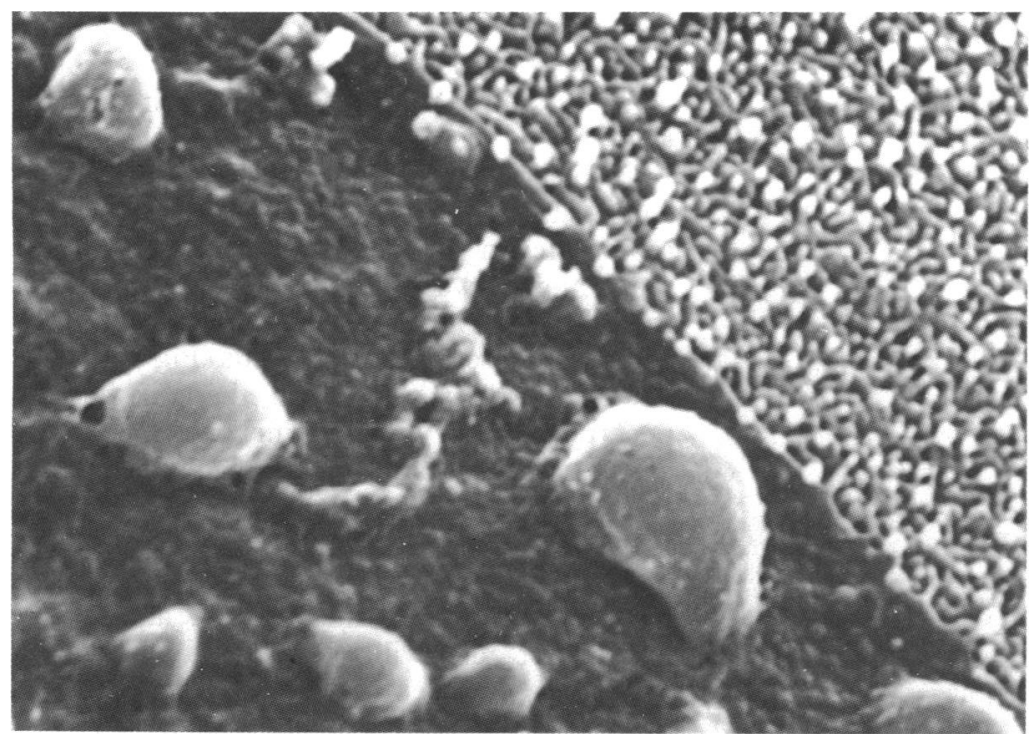

Figure 3 Large deposits on a 'dark' cell devoid of microvilli. Tiny and numerous deposits on microvilli of the adjacent cell $(S E M \times 7500)$.

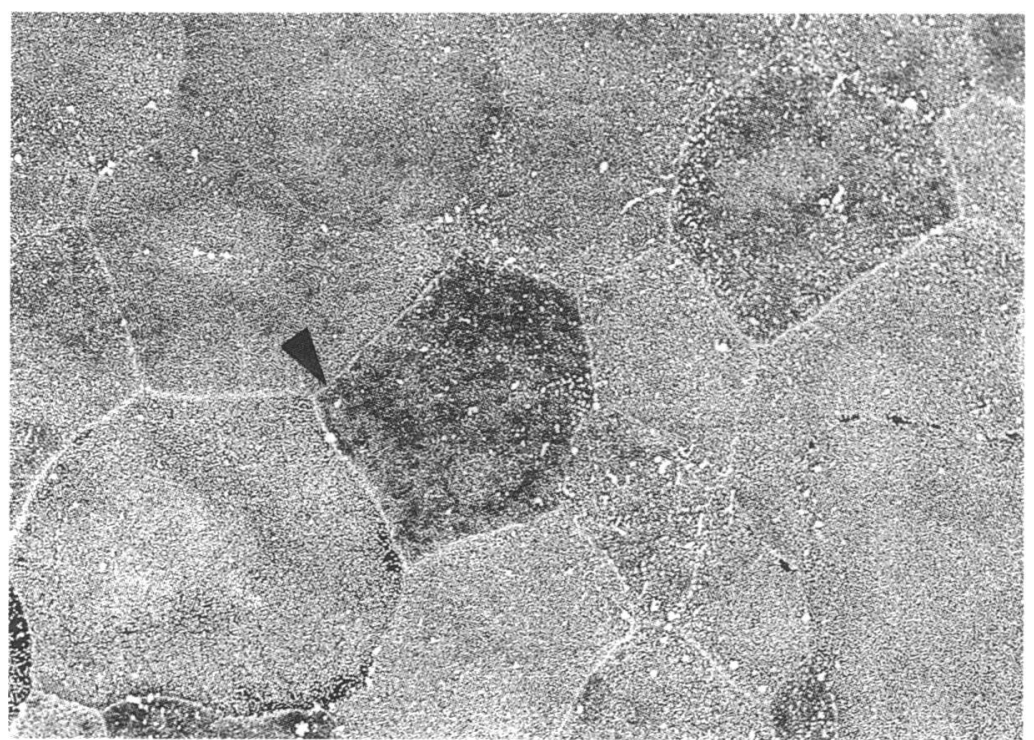

Figure 4 A control SEM: the other half of the same cornea instilled only with $0.9 \% \mathrm{NaCl}$. $A$ characteristic pattern of normal superficial cells. A 'dark' cell (arrow) $(S E M \times 1400)$.

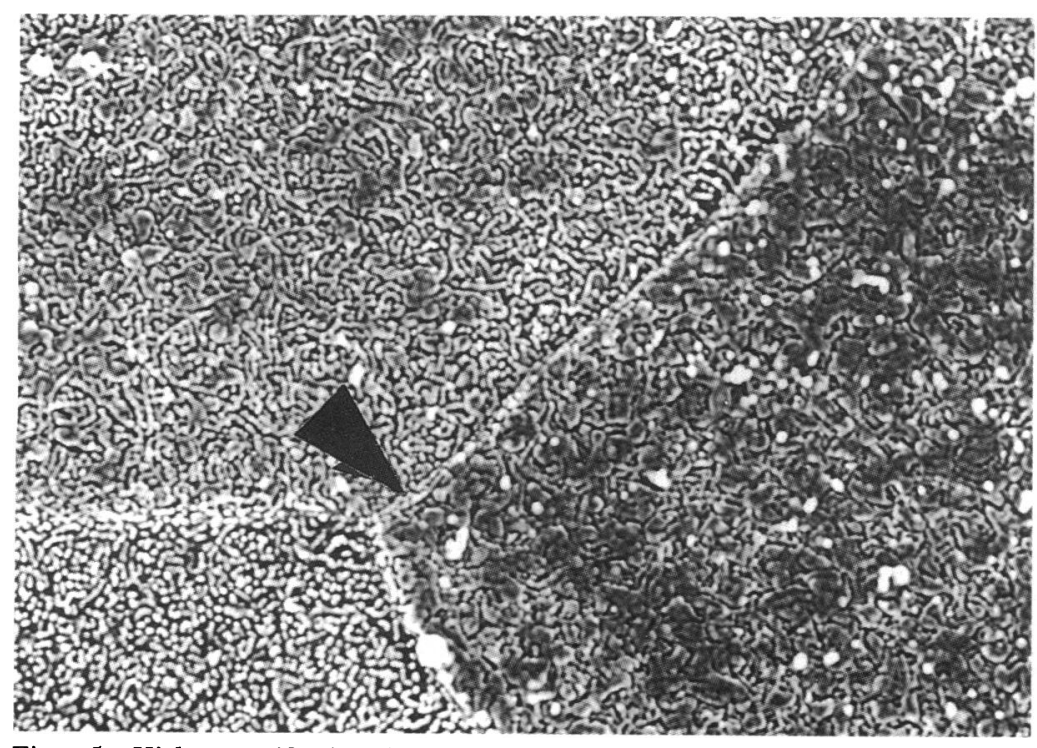

Figure 5 Higher magnification of a detail of Figure 4, explaining the phenomenon of the 'dark' cell. The dark-light contrast of the cell is still visible $(S E M \times 3700)$. prepared for scanning electron microscopy (SEM). Another human cornea was similarly prepared. We examined a further two human corneas with SEM, so we had four control specimens.

\section{Results}

The cytotoxicity of $0.5 \%$ amethocaine was evaluated according to morphological changes of the epithelial corneal cells.

\section{AMETHOCAINE DEPOSITS}

Amethocaine deposits were present on microvilli (Fig 1) or on cell membrane devoid of microvilli (Figs 2 and 3). The deposits were of different sizes, round or lump-shaped, and scattered densely over numerous cells of the corneas. They appeared only after instillation of $0.5 \%$ amethocaine as they were not seen on the control corneas instilled with just $0.9 \% \mathrm{NaCl}$ (Figs 4,5 , and 6).

\section{LOSS OF MICROVILL}

Some cells showed rarefaction of microvilli while numerous cells were completely devoid of them (Figs 2 and 3). A comparison with undamaged, control cells (Figs 4, 5, and 6) suggested that the loss of microvilli was the result of the installation of $0.5 \%$ amethocaine.

\section{INCREASED DESQUAMATION}

The major cytotoxic effect of amethocaine was increased desquamation of 'light' cells (Fig 7). SEM demonstrated some superficial cells at the moment of their desquamation (Fig 8).

DAMAGE TO THE CELL MEMBRANE

At higher magnifications, ruptures were seen on the desquamated cells (Fig 8).

CONTROL

The damaged cells were compared with the normal ones. Figures 4, 5, and 6 showed normal superficial cells of the human cornea. It was possible to make an ideal comparison between two halves of the same cornea: one half instilled with $0.5 \%$ amethocaine and another instilled with $0.9 \% \mathrm{NaCl}$. The small number of 'dark' cells (Fig 4) indicates an intact corneal surface with a normal desquamation rate.

The phenomenon of the 'dark' cell, explainable by the difference between microvilli, is present in Figures 4, 5, and 6. Microvilli of the 'dark' cell appear flattened, as they were compressed by the overlying older 'light' cell before desquamator of this 'light' cell occurred.

\section{Discussion}

The main effect of ocular local anaesthetics is the prevention of pain, but their toxic side effects are responsible for damage to epithelial cells. While the process involved in pain blocking is well understood, the molecular and cellular mecha- 


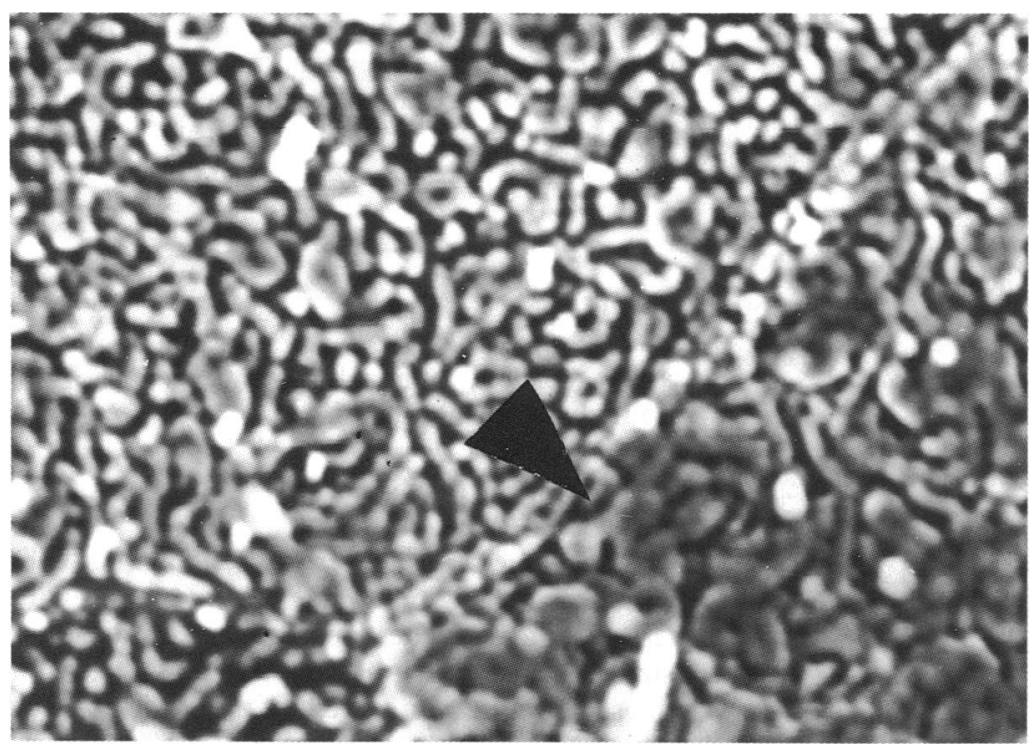

Figure 6 Higher magnification of a detail from Figure 5. The 'darkness' of the cell (arrow) is hardly visible. Normal microvilli $($ SEM $\times 12000)$.

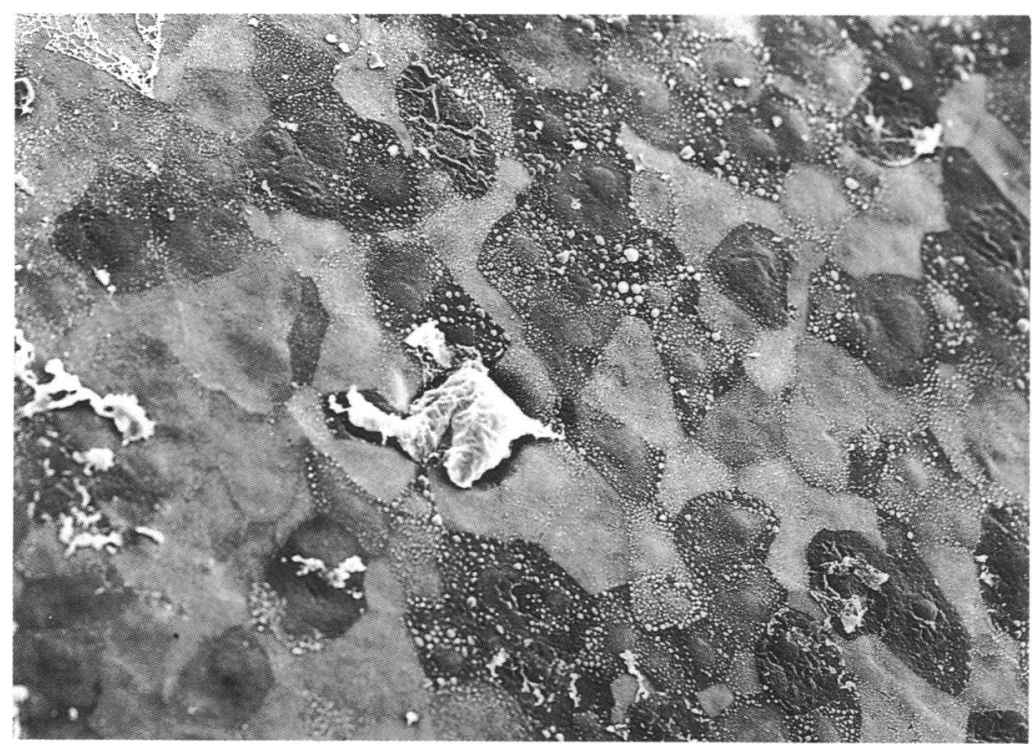

Figure 7 Corneal surface following application of $0.5 \%$ amethocaine. An increased desquamation of 'light' cells. A desquamated cell in the middle $(S E M \times 300)$.

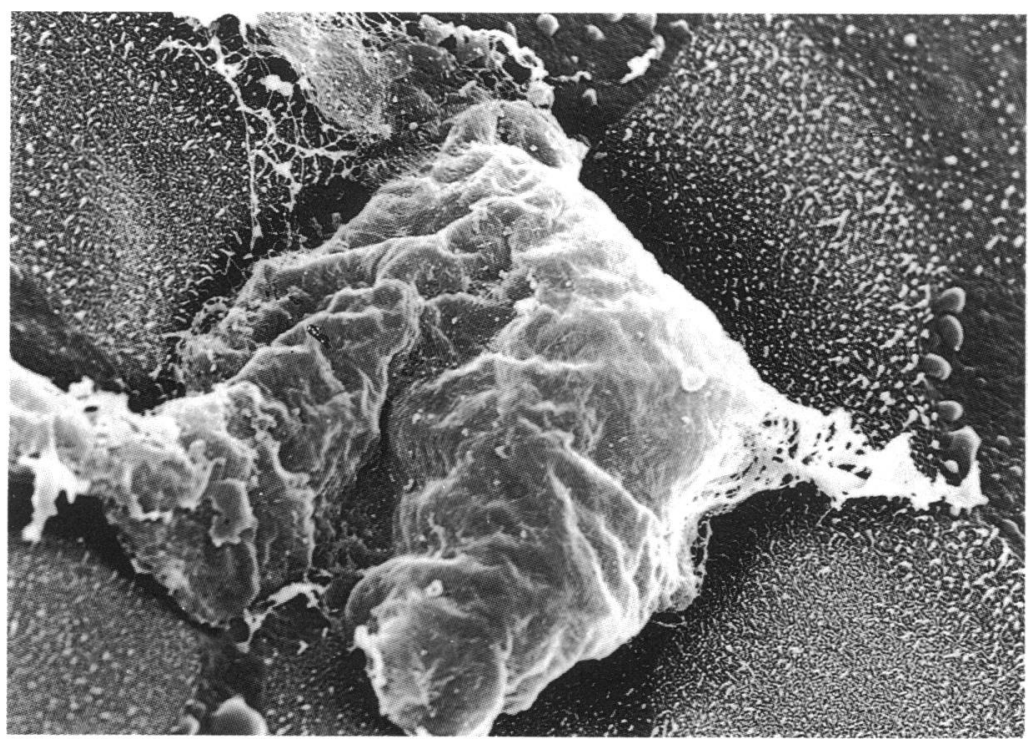

Figure 8 Higher magnification of Figure 7. The desquamated epithelial cell damaged by $0.5 \%$ amethocaine, shows a folded surface and disrupted membrane $(S E M \times 1600)$. nisms of the toxicity of local anaesthetics have not yet been satisfactorily clarified. ${ }^{18}$

In our study the toxic effects of amethocaine were seen on the cell membrane and microvilli of epithelial cells. Amethocaine deposits demonstrated by SEM in Figures 1, 2, 3, and 8 represented a morphological substrate of the interaction between amethocaine and proteins of the cell coat. The engulfing of deposits into the cytoplasm observed in some cells (Fig 2) may be one of the ways in which the amethocaine penetrates the cytoplasm, thus causing damage of the cell membrane and, finally, cell death (Fig 8).

Rarefaction and loss of microvilli may be also the consequence of toxic effects of amethocaine deposits on the microvilli (Figs 1, 2, and 3). The damage of microvilli leads to the increased desquamation, demonstrated by SEM as a decrease in the number of 'light' cells (Fig 7). It is known that, during the process of desquamation, the interdigitation of microvilli is diminished and many contacts between them are interrupted. ${ }^{17} 19$ Similar alterations to microvilli were demonstrated by SEM in the rabbit cornea following exposure to ultraviolet radiation..$^{20}$ One of the reasons for the toxicity of amethocaine is change in $\mathrm{pH}$. The most commonly used local anaesthetics belong to the benzoic acid ester group, and are weak bases - for example, $0.5 \%$ amethocaine has a $\mathrm{pH}$ of $3 \cdot 7$ to $6 \cdot 0$.

Reversibility of toxic effects of local anaesthetics can be demonstrated only in animals. Thus, toxic effects of one drop of oxybuprocaine (Novesin) instilled in a rabbit cornea are reversible within 60 minutes after instillation. ${ }^{16}$ Leuenberger, ${ }^{17}$ who used SEM to study the toxicity of local anaesthetics applied to the rat cornea five to 15 times at intervals of 30 minutes, reported a decreased number of 'light' cells and loss of microvilli. His transmission electron microscopic (TEM) studies revealed a reduced number of desmosomes, and ruptures of cell membrane and vacuoles in the cytoplasm. Harnisch ${ }^{16}$ reported TEM studies on side effects of anaesthetics on the epithelial cells of the rabbit cornea, where he revealed all stages of cell degeneration, including rarefaction of microvilli.

Toxicity of local anaesthetics depends on their rate of elimination. Despite the very slow rate of hydrolysis of local anaesthetics, their toxicity is soon diminished by a continuous flow of tears, washing away amethocaine and cells contaminated with the anaesthetic. Local anaesthetics are known to delay healing of epithelial corneal defects because they inhibit epithelial sliding. ${ }^{21}$

The comparison between SEM and slit-lamp observations of anaesthetised cornea is interesting; both show the same cytotoxic effects of local anaesthetics on the patient's cornea. By slit-lamp very small, white dots are visible, representing groups of denaturated superficial cells; the pathological prolongation of breakup time (BUT) is a result of the increased cell desquamation.

Adverse side effects of a single instillation of a local anaesthetic are always mild and reversible in 1-3 hours. However, anaesthetic induced keratopathies are extremely rare, despite extensive use of local anaesthetics in everyday ophthalmic practice. 
The authors thank'Professor Dr N Pipan and Dr M Pšenienik for their help in scanning electron microscopic examinations.

1 Strichartz GR, Ritchie JM. The action of local anesthetics on ion channels of excitable tissues. In: Strichartz GR, ed. Local anesthetics. Handbook of experimental pharmacology. Vol 81. anesthetics. Handbook of experimental phar

2 Ritchie JM, Greene NM. Local anesthetics. In: Goodman LS, Gilman A, eds. The pharmacological basis of therapeutics. New York: Pergamon Press, 1990: 312-31.

3 Koller K. Ber dtsch ophthal Ges 1884; 16: 60. In: Duke-Elder S System of ophthalmology. Vol VII. London: Kimpton, 1962 601.

$4 \mathrm{Knapp} \mathrm{H.} \mathrm{On} \mathrm{cocaine} \mathrm{and} \mathrm{its} \mathrm{use} \mathrm{in} \mathrm{ophthalmic} \mathrm{and} \mathrm{general}$ surgery. Arch Ophthalmol 1884; 13: 402-48. 5 Fuchs E. Ueber Cocain. Wein Klin Wochenschr 1902; 15:

6 Dolder R, Skinner FS. Ophthalmologika. Stuttgart: Wissenschaftliche Verlagsgesellschaft, 1990: 320-2.

7 Marx E. Untersuchungen über Pantocain. Klin Monatsbl Augenheilkd 1932; 89: 209-14.

8 Behrendt T. Experimental study of corneal lesions: produces by topical anesthesia. Am f Ophthalmol 1956; 41: 99-105. Hilsdorf C, Zenklusen G. Novesinschaden der Hornhaut. Klin Monatsbl Augenheilkd 1973; 162: 525-7.

10 Klima M, Ruckerova H. Severe eye damage due to oxybuprocaine. Cesk Oftalmol 1974; 30: 375-80.
11 Pau H. Anesthetikum-Keratitis. Klin Monatsbl Augenheilkd 1980; 176: 885-92.

12 Jallet G, Cleirens S, Girard E, Bechetoille A. Keratopathie toxique grave à l'oxibuprocaine d'apparition particulierèment rapide. Bull Soc Ophtalmol Fr 1980; 80: 385-7.

13 Henkes HE, Waubke TN. Keratitis from abuse of corneal anaesthetics. Br $\mathcal{F}$ Ophthalmol 1978; 62: 62-5.

14 Penna EP, Tabbara KF. Oxybuprocaine keratopathy: a preventable disease. $B r$ F Ophthalmol 1986; 70: 202-4.

15 Rosenwasser GO, Holland S, Pflugfelder SC, Lugo $M$ Heidemann DG, Culbertson WW, et al. Topical anesthetic abuse. Ophthalmology 1990; 97: 967-72.

16 Harnisch JP, Hoffman F, Dumitrescu L. Side-effects of local anesthetics on the corneal epithelium of the rabbit eye. Graefes Arch Klin Exp Ophthalmol 1975; 197: 71-81.

17 Leuenberger $P$. Die Stereo-ultrastrukture der Kornealoberfläche bei der Ratte. Graefes Arch Klin Exp Ophthalmol 1970; 180: 182-92.

18 Butterworth JF, Strichartz GR. Molecular mechanisms of local anesthesia: a review. Anesthesiology 1990; 72: 711-34.

19 Pedler C. The fine structure of the corneal epithelium. Exp Eye Res 1962; $1: 286-9$.

20 Hoffmann F, Schweichel J. The microvilli structure of the corneal epithelium of the rabbit in relation to cell function Ophthalmic Res 1972; 4: 175-84

21 Marr WG, Wood R, Senterfit L, Sigelman S. Effect of topical anesthetics. Am f Ophthalmol 1957; 43: 606-10. 